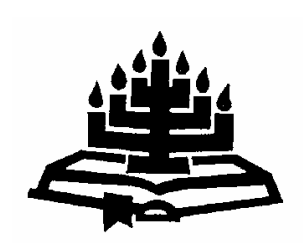

\title{
The inductive form of preaching (F.B. Craddock) - an exploration and evaluation
}

\author{
C.J.H Venter \& S.J. Bang \\ School of Ecclesiastical Sciences \\ Potchefstroom Campus \\ North-West University \\ POTCHEFSTROOM \\ E-mail: kwscjhv@puk.ac.za \\ sjdavidbang@hotmail.com
}

\begin{abstract}
The inductive form of preaching (F.B. Craddock) - an exploration and evaluation
\end{abstract}

Within the wider field of research in homiletics special emphasis has been placed on investigation dealing with hermeneutical homiletics. In Europe Dingemans initiated research focused on this specific field of homiletics in 1991. In South Africa the research and findings of Pieterse and Vos on hermeneutical homiletics are prominent at this stage. The emphasis in research on this aspect of homiletics has, however, in a sense been preceded by the work of Fred Craddock - work that has till date not been highlighted and evaluated sufficiently by South African theologians. Craddock's work in this field may be regarded as transitional in nature. In Craddock's approach the focus has shifted from research dealing mainly with the formal aspects of preaching to research bringing into perspective, among others, an inductive form of preaching. In applying the inductive form of preaching the function of the hearer as interpreter is utilised. The power and generative use of language in a sermon is also brought to the fore in this form of preaching. Craddock has indeed brought to light core elements in homiletical research - elements still serving as a stimulus for research on hermeneutical homiletics. Craddock's approach to preaching - the inductive method - directs the attention to the structure of the sermon, as well as the "movements" and the development of the train of thought within the sermon as essential elements of inductive preaching. Furthermore, the aim of uniting the different elements of the sermon and the use of 
imaginative language in a sermon is also stressed by Craddock's method. In conclusion this article attempts an evaluation of some of Craddock's viewpoints on preaching.

\section{Opsomming}

Die induktiewe preekvorm (F.B. Craddock) - 'n verkenning en evaluering

In die wye veld van homiletiese navorsing is die afgelope aantal jare gefokus op hermeneutiese homiletiek. In Europa het Dingemans in 1991 met hierdie baanbrekerswerk begin en in Suid-Afrika het veral Pieterse en Vos waardevolle verbandhoudende momente in hulle navorsing na vore gebring. Tog is bogenoemde navorsing in 'n sekere sin voorafgegaan deur die stimulerende effek wat die navorsing van F.B. Craddock gehad het - navorsing wat tot nog toe nie genoegsaam uitgelig en beklemtoon is nie. Craddock kan beskou word as 'n oorgangsfiguur tussen homiletiese navorsing wat sterk gerig was op die formele aspekte van die preek as sodanig en die induktiewe wyse van preek, waarin onder andere in besonder gefokus word op die interpreteringsfunksie van die hoorder en ook op die werking van taal in die prediking. Craddock het inderdaad kernelemente vir 'n nuwere tyd in homiletiese ondersoek blootgelê. Hierdie elemente word saamgevat onder die noemer induktiewe prediking. In hierdie artikel word die volgende elemente van die induktiewe preekmetode van nader beskou: struktuur en "bewegings" as kernaspekte in die preek, eenheid in die preek en verbeeld-ing in 'n preek deur middel van taal. Laastens word Craddock se werk op die terrein van induktiewe prediking geëvalueer.

\section{Introduction}

In 1958 Davis published his views on homiletics in Design for preaching, the main argument of which was that a sermon's "germinal thought" or "generative idea" has an energy, a vitality, inherent in itself (Davis, 1958:21). A few years later Davis's thoughts proved to be germinal indeed later when Fred Craddock's work on inductive preaching As one without authority was published. This seminal publication, the third published in 1981, is widely recognised as a watershed work in contemporary homiletics. As one without authority was preceded by Craddock's Overhearing the Gospel (1978) and followed by Preaching in (1985). The result was that inductive preaching has come to be commonly associated with Fred B. Craddock in contemporary homiletical literature (Hamilton, 1992: 9; Venter, 2002:2-3; Bang, 2004:65-66). Craddock indeed makes a strong case for the inductive method of preaching. He is convinced 
that the inductive method is a form of preaching that incarnates the message of Christianity, being a homiletic form well suited to the content of the Gospel and the nature of the Christian faith (Craddock, 1981:3-4).

This article will attempt to explore Craddock's form of preaching, the inductive form, taking as point of departure the categories of structure, movement, unity and the use of imaginative language in the sermon. This analysis will be followed by an evaluation.

\section{Structure and movement}

While the elements of structure and movement are closely linked in the inductive form of preaching, both elements are treated together in this section of the article.

Assuming that the preacher has heard the Word of God and that interaction between text and congregation has occurred, what is to be the form of the sermon? Craddock notes that there is no form in the Bible that can be designated "the form of a sermon". If anything, the presence of a great variety of literary forms in the Bible calls for a diversity in sermonic forms (Craddock, 1985:171-172; cf. Pieterse, 1985:170-202; Vos, 1995:436-468; Long, 1989; Long, 1993).

A preacher has the alternatives of either selecting a form or of creating a form. Many preachers turn to the biblical text itself for the sermon form they eventually select and Craddock encourages this congruence of biblical form and message. As a matter of fact, Craddock believes that several advantages exist in structuring a sermon in the light of the biblical text. It ensures inter alia variety in form; it enhances the integrity of the sermon if both its form and content come from the same source. Furthermore it encourages a preacher to discover the purpose of the biblical form (praise, correction, encouragement, judgement) and to reflect that purpose in his preaching (Craddock, 1985:178; cf. Adams, 1982:31; Chapell, 1995:4; Venter, 2002:7). Finally, the question, "Will a change of form from the text to sermon alter the meaning of the text for the listeners?" (Craddock, 1985:179) strengthens the awareness of the sermon's reception. For these reasons then, there is great value in sermon forms that are rooted in the biblical text itself (cf. Pieterse, 1979; Goldsworthy, 2000:31-33).

Craddock (1981:139) further argues that a preacher may choose to create a form in accord with the inductive method which demands two things of a sermon outline. 
- In inductive preaching, structure is subordinate to movement. The preacher's primary concern is making the flow of ideas coherent while concerns about structure are secondary. Indeed, with inductive preaching, structure, which is often not noticeable to the congregation, exists to facilitate sermonic movement. Craddock (1981:140) suggests that "Usually, for the skeleton to be showing, with a sermon as with a person, is a sign of malformation or malnutrition".

- When utilising the inductive form of preaching, the outline starts with the present experience of the hearers and moves to the point at which the sermon leaves the hearers to make their own decisions and conclusion. "It bears repeating that a preaching event is a sharing in the Word, a trip; not just a destination and not handing over of a conclusion" (Craddock, 1981:146; cf. Buttrick, 1994:82).

A preacher needs to consider several dimensions of the movement of the sermon in relation to its structure. Craddock makes several practical suggestions.

- One should begin the preparation of the sermon with the conclusion, not the introduction, for the beginning point of the actual preparation process is knowing where the preacher and the congregation are heading to. It may even be helpful to write one's conclusion at the bottom of a piece of paper.

- Plan the trip to the conclusion in outline form, on a sheet of paper, keeping in mind that it is important to sustain anticipation if all persons and all the faculties of each person are to complete the complete journey. Playing on Mark 2:27, Craddock (1981:148) states that "The outline is made for man, not man for the outline".

- In the interest of creating an outline that sustains anticipation and hence movement, Craddock remarks that a preacher can learn much about the way to gain the involvement and participation of his hearers by reflecting on poems, essays and parables that proved effective in his own experience (Craddock, 1981:148149). Craddock (1985:166) thus states that effecting the quality of anticipation is a primary taste of movement in a sermon (cf. Vos, 1995:520-524).

The question can thus be asked, where one does get an actual outline or structure for an inductive sermon? Craddock concedes that there is no single model or source. A strategy for the preacher 
struggling to find a form for a cluster of ideas is to adopt the form of the biblical text being preached. Craddock (1981:153) emphasises that "If the speech-forms of the Bible were adopted, sermons would be strengthened by the fact that the text would not be forced to fit a new frame" (cf. also Mayhue, 1990:117; Lawson, 2001:198-217). Although the very nature of the inductive sermon means there is no single inductive outline or pattern, Craddock offers several suggestions for those who wish to use inductive movement in preaching.

- Since preaching implies oral communication, preachers are advised to prepare their sermon with a view to how it will be preached. Craddock (1981:154-155) states that "It is reasonable that one operates as much as possible in preparation as one will operate in delivery".

- It may also be helpful to list ideas in brief phrases or sentences in order of occurrence, asking if the material moves and sustains interest to the end.

- Maintain the image of a trip by identifying the transition points in the story and marking them with appropriate phrases (Craddock, 1981:155).

- Underline the transitional phrases, using them as pegs upon which to hang a series of ideas. By noting these transitional expressions, a preacher can readily see the movement of his thought and the shape of his emerging sermon. The sole purpose is to engage the hearer in the pursuit of an issue or an idea so that he will think his own thoughts and experience his own feelings in the presence of Christ and in the light of the Gospel (Craddock, 1981:157; cf. De Wet, 1995:36-40; Van der Vyver, 1990:65-134).

What does an inductive sermon look like in actual practice? Essentially it consists of a series of movements of ideas and thoughts that progresses toward a climax. The smaller units of the sermon are linked together by transitional phrases that enable a listener to put the pieces together. In short, the inductive sermon form focuses on making the flow of ideas coherent so that it corresponds to the way people usually experience reality and to the way life's problem-solving activity goes on naturally and casually (Craddock, 1981:66). Craddock concludes his discussion of sermonic structure and movement by noting that members of the congregation may experience inductive sermons as one long introduction with an implied point at the end. Although a minister 
may interpret such remarks in a variety of ways, it may indicate, says Craddock, that the people cannot shake off the finished sermon as easily as they shake the minister's hand. The sermon, not finished yet, lingers beyond the benediction, with conclusions to be reached, decisions made, actions taken and brothers sought, while gifts lie waiting at the altar (Craddock, 1981:158).

Craddock is convinced that movement is an important methodological consideration for effective preaching (cf. Buttrick, 1994:82). According to Craddock there are basically two directions in which thoughts move: a deductive and an inductive way.

Craddock argues that the inductive approach to preaching is a commendable, contemporary communication strategy. He (Craddock, 1981:55) notes that by using this approach, thoughts move from the particulars of experience that have a familiar ring in the listener's ear to a general truth or conclusion (cf. Johnston, 2001:151-155). An inductive approach to preaching has at least two advantages.

- It is an approach to preaching in which the method of proclamation and the method of preparation coincide. On the pulpit on a Sunday morning the preacher simply replicates the inductive movement of thought experienced in his/her study during the week (Craddock, 1981:162).

- The inductive form is a method of preaching that empowers the hearers to apply the conclusion to their own lives. Craddock (1981:57) argues that "If they have made the trip, then it is their conclusion, and the implication for their own situation is not only clear but personally inescapable".

Craddock replies that two matters are theologically basic to the inductive method. When preaching to the congregation a preacher acknowledges that he addresses the people of God and hence, the preacher's message is the people's message. Craddock (1981:60) argues, "He speaks not only to them but for them and seeks to activate their meanings in relation to what he is saying". Even when preaching to people not formally members of the church, the preacher acknowledges that a point of contact, rooted in the imago Dei, exists between the listener and God. Thus, Craddock (1981:61) stresses that in inductive preaching, "the congregation is more than just the destination of the sermon" (cf. also Pieterse, 1991:40-45; Van Harn, 1992:137-149). 
Craddock emphasises three aspects of the relationship between inductive movement and the listener.

- Concrete experiences common to both the preacher and the listeners are integral to the inductive sermon. Craddock (1981:59) remarks that, "Fundamental to the inductive movement, therefore, are identification with the listener and the creative use of analogy" (cf. also Johnston, 2001:18-19). A preacher and a listener are inextricably linked by virtue of their shared experiences communicated in the preaching moment by means of analogies drawn from daily life (cf. Long, 1993:167-188). Craddock (1981:59) continues, "It cannot be overemphasized that the immediate and concrete experiences of the people are significant ingredients in the formation and movement of the sermon and not simply the point at which final applications and exhortations are joined" (cf. also Pieterse, 2001:19-75; Willhite, 1992:355-369).

- Respect for the capability and the right of the hearers to participate in the movement of the sermon and to arrive at their own conclusion, is fundamental to the inductive approach (Craddock, 1981:62-63). "The advantage of this type of movement is that it creates and sustains interest, and it does so by incorporating anticipation." The inductive sermon capitalises on life's healthy and interesting moves from expectation to fulfilment.

- The third aspect of the relationship between inductive movement and the listener pertains to the listeners' responsibility to complete the sermon. This invitation to the hearer to complete the sermon is characteristic of God's way of relating to human beings. Craddock (1981:65) states that "One could characterize God as reticent to be obvious, to be direct and hence to overwhelm, even when men called for some clear and indisputable evidence from heaven". Thus, the inductive approach to preaching calls for incompleteness and a lack of exhaustiveness in the sermon itself, a difficult assignment for preachers who want to guarantee that their message is heard.

Craddock (1981:123) notes that recent attempts to travel the distance from text to sermon have revealed that, while the processes of exegesis and preaching are not identical, they are, nonetheless, inseparable (Craddock, 1981:110); they are distinct, yet interrelated activities. The problem at this point for Craddock is that sermons that unhook exegesis and preaching lack unity and movement, whereas sermons that exhibit these qualities tend to dispense with either the biblical text or the contemporary situation. 
Craddock makes two suggestions in response to the question whether there is another alternative.

- In first instance, Craddock invites preachers to use the same inductive process in delivery as used in the preparation of his sermon. In traditional preaching, laments Craddock, the route from studying the text to structuring the sermon is like ascending a hill (inductive exegesis in the study) and then descending a hill (deductive sermonising on the pulpit) with the congregation experiencing only the deductive side of the shift from the inductive to the deductive movement of thought.

Thus, while the preacher experiences the thrill of discovery as he ascends the hill by means of his inductive study of the text, the people experience no such joy, for they must descend, starting with the preacher's conclusion, the summit of his work, and then moving down deductively to a consideration of the various liferelated applications of his thesis. Craddock (1981:123-125) says "What's wrong is the movement. Why not make the method of proclamation the same as the method of preparation?"

- Secondly, if movement and unity en route from exegesis to sermon is to be achieved, says Craddock, then a preacher should give greater attention to the place of the congregation. Craddock (1985:98) argues, "Giving disciplined time and attention to the interpretation of one's listeners is critical for preaching". Indeed, in reality, a preacher does not study the text alone, or without his people, but rather he studies the text from the perspective of the congregation's situation, bringing the congregation's circumstances to bear upon his understanding of the text and its message for them (Craddock, 1981:126). Craddock (1981:132) recommends that the movement be dialogical: " ... the experience is not of a trip from text to people or from people to text but ... both are actively involved" (cf. also Johnston, 2001:152-155).

\section{Unity}

If movement within a sermon is a primary characteristic of effective and persuasive preaching, then unity is essential to that movement (Craddock, 1981:100). Indeed, Craddock (1981:100) insists "There can be no movement without unity, without singleness of theme". While the inductive sermon does not have "points", it does have a point, a single theme that governs the preacher's selection and rejection of material for the sermon. Craddock (1981:100) states, "The contribution to the movement and power of a sermon made by 
the restraint of a single idea can hardly be overstated". In fact, the discipline of this one idea contributes to the preparation, delivery, and reception of a sermon (cf. Venter, 2004:1-15).

While preparing the sermon, the restraint of one governing idea releases the imagination. For Craddock, it is crucial for the topic to be firmly fixed in the preacher's mind as she/he prepares the sermon.

A broad topic or theme has no center of gravity, it draws nothing to itself ... But not so the precise and clear thesis. Like a magnet it draws potentially helpful material from current and remembered exposures to people and books (Craddock, 1981:100).

With a single idea in mind, the preacher is free to assemble a sermon, excluding what is irrelevant and including that which is pertinent to the single germinal idea that is the destination of his/her sermon (Robinson, 2001:35, 104). During the delivery of the sermon, the presence of a single theme contributes to the forcefulness with which the sermon is communicated. For Craddock (1981:101) "The difference between sermons with the constraint of a single idea and those without such a constraint is like time difference between a moving stream and a stagnant marsh". The presence of a governing theme focuses the energy of the preacher on the unfolding of the single germinal idea that is the point of the sermon. Moreover, while listening to a sermon, the presence of a single focus contributes interest and meaning. Craddock (1981:102) says, "Unity does for the sermon what a frame does for a picture".

How can the preacher say one thing and say it well?

- A thorough exegetical analysis of the text is really the only way to discover the governing theme for the sermon. Exegesis will indicate that, although the text may contain a cluster of ideas, all those ideas are really subordinate to a larger umbrella theme which may be treated in a single sermon or by means of several (cf. Adams, 1982:24-50).

- Furthermore, the desire to be thorough in one's treatment of a text may lead the preacher to sacrifice unity of theme. The preacher should thus take the time to discover the point of the story and allow that point to govern all other considerations.

- Also to be kept in mind is that a preacher should guard against the seduction of using the concordance to create a sermon. A preacher should resist any temptation that short-circuits 
struggling, studying and wrestling with the biblical text in search of a governing idea. This central idea is the key to a forceful sermon. Although unity may be difficult to achieve, Craddock (1981:105) stresses that "the desired unity has been gained when the preacher can state his central germinal idea in one simple affirmative sentence" (cf. Venter, 2002:9-10).

Craddock observes that most sermons today exhibit a broken unity with part of the sermon oriented toward the past and the other part oriented toward the present. The primary reason for this lack of unity is the bi-polar nature of the task of preaching, or at least, of preaching that seriously struggles with what the biblical text said and what the text says. For Craddock, unity is essential to movement in preaching, but this unity requires an interpretive approach that bridges the distance between the past and the present with substantial continuity (cf. Strydom, 1989:23-27). As Craddock (1981: 117) emphasises, "the absence of serious interpretation of the biblical text endangers the Christian character of the sermon while the presence of such biblical interpretation endangers the movement of the sermon and the unity essential to that movement".

\section{Imagination and imaginative language use}

Imagination and the use of imagery is a type of creative thought that is in contrast to the creativity of logic. "By logic alone we can never arrive at faith. Faith is a matter of imaginative discernment of truth through paradox and contradiction in addition to logical discernment" (Wilson, 1993:145).

Craddock concedes that the inductive form of preaching makes a heavy demand upon the preacher's imagination. If the members of the congregation are to hear the text as the preacher heard it in his study, then the preacher will not be satisfied to reduce his/her experience to conceptual structures like points, logical sequences, and moral applications. The preacher who desires to reflect what she/he has experienced will do so, Craddock (1981:77) argues in paraphrase of Martin Heidegger, by means of "evocative images rather than conceptual structures".

Although imagination and imaginative language are crucial to all types of thinking and problem solving, Craddock believes its significance in our day has been reduced by those who associate imagination with fantasy alone. Yet, in Craddock's (1981:79) view, imagination, like hope, is essential to life "because imagination is ingredient to hope". For example, no thinking person would reduce 
hope's image of the lion and the lamb lying together to fantasy. Images are critical to the preaching event. Craddock (1981:80) argues, "By means of images the preaching occasion will be a recreation of the way life is experienced now under the Gospel" (cf. Brits, 2001:146).

The preacher's imagination is best nurtured, maintains Craddock, not by focusing on the use of imaginative words, but by cultivating the preacher's ability to receive images. The preacher must remain alive to the ordinary sights and sounds of life.

If the imagery of his sermons are to be real he (the preacher) must see life as life, not as an illustration under point two (Craddock, 1981:81).

Reading quality literature helps to keep the preacher sensitive towards life, especially reading in the absence of the pressure of preparing for the next sermon. The preacher's involvement in the life of the congregation is also an important factor in nurturing his/her capacity for empathetic imagination. Taylor (1993:213) emphasises that "imagination is the ability to form images in the minds of [...] listeners that are not physically present to their senses, so that they find themselves in a wider world with new choices about who and how they will be". Craddock (1981:92) argues that "The preacher's task is to use evocative imagery that will allow his congregation to see and hear what he (she) has seen and heard". What the preacher has seen and heard, however, is not information about God but "our existence as it is in the liberating light of God's graciousness toward us" (Craddock, 1981:92; cf. Callahan, 1999: 162).

But how does one preach "so that the images he (the preacher) has received are formed in the imagination of his hearers with clarity and force sufficient to effect changes in attitudes, values, and life directions?" (Craddock, 1981:92). Five principles are critical to the function of imagination in preaching.

- The images should be drawn from ordinary life and cast in forms recognisable as real and possible (Craddock, 1981:92).

- Since the force of a sermon depends upon communication that will be recognised by the hearers, the preacher's words need to be concrete so that they convey what can be heard, seen, smelled, touched or tasted. For example, "if the sermon revives the memory of the odor of burped milk on a mother's blouse it evokes more meaning than the most thorough analysis of 
'motherhood' " (Craddock 1981:93). The economic use of words is a further principle which the preacher should respect since communication, like revelation, must leave room for discovery (Craddock, 1981:94).

- Craddock also encourages the preacher to avoid all selfconscious interruptions in narration and description (Craddock, 1981:95; cf. Johnston, 2001:149-155). For example, interrupting the sermon with phrases like "We find in this story" or "We see out this window" only serve to draw attention away from the sermon to the preacher.

- Finally, Craddock appeals to the preacher to use the vernacular on the pulpit if he wishes to communicate with images that awaken his hearer's imagination (cf. also Wilson, 1993:131-146). "The language used is to be one's own" (Craddock, 1981:95).

These five principles guide the preacher in his capacity to express what has been impressed upon him by life.

Of course, there are objections to the use of the aesthetic in homiletics, notes Craddock. Some may argue that it fails to contribute to human transformation, and others that it does not appeal to everyone. Craddock (1981:86-90), however, replies that "preaching's burden is to share the whole Gospel with the whole man".

It seems as if Craddock links up with aspects of Ricoeur's view on language. Janse van Rensburg (2000:84) has indicated that Ricoeur has a dynamic understanding of language. He (Ricoeur) substitutes a system of language in which not merely the meaning of the words, but rather the dynamic process to which the language usage refers, becomes the focus of interest. Thus the text becomes more important than the intentions of the author when he wrote language signs. The apparent meaning of a text is redefined by the hidden meaning, construing an inductive path of interpretation. Symbols have no meaning before and outside of speech (Janse van Rensburg, 2003:85).

\section{Evaluation}

A first positive point of Craddock's strategy for effective communication in preaching is his emphasis on the value of movement within the sermon. As Eslinger (1987:123) states, "for him as well as Lowry, preaching without movement is a homiletical mortal sin". For Craddock, sermonic movement is what sustains congregational interest in the preached Word. Craddock's emphasis 
on movement in a sermon is indeed positive and a result of a resistance against a thematistic form of preaching. A thematistic form of preaching implies that "points" or subdivisions are forced from outside the preaching text on the text itself, without in any way keeping in mind the movements in the text itself. The reaction against this enforcement of points in a sermon concretised in the inductive form of preaching, versus the deductive form. The question can be asked - with all appreciation for positive core elements brought forward in the inductive form of preaching - whether the deductive form of preaching should be totally abandoned. Is it totally impossible to communicate inductively with a congregation in a "deductive" way, especially in sermons teaching the listeners step by step in an organic way from the Word of God? Cox (1990:62) remarks, "I believe that it would be impossible to do a thorough job of consecutive Bible exposition or give a good account of the Bible's teaching without going at our task much of the time deductively". Craddock further utilises movement in the "structure" of a sermon by stating that in inductive sermons the outline starts by moving from the particulars of experiences known to the hearer to discover a general truth or come to a certain conclusion in the sermon. This approach may certainly be a way of accomplishing this aim, but can this possible outcome be limited only to the inductive method of preaching? Can the above-mentioned aim not also be accomplished by combining inductive and deductive methods of preaching? Is the viewpoint of Craddock that structure in a sermon is subordinate to movement in a sermon, and should therefore not be seen or heard in a sermon, not questionable? Does structure not rather serve to unite the different elements of the sermon? Does structure not also have the function of promoting movement in a sermon by the very process of structuring the theme of a sermon meticulously?

A second positive asset of Craddock's strategy for effective communication in preaching has to do with what it posits about the goal of the preaching event. In his earliest work, Craddock (1981:63) argues that "fundamental to induction is movement of material that respects the hearers as ... deserving the right to participate" in the anticipation that "moves from expectation to fulfillment". Although many contemporary preachers have learned to express themselves almost entirely in writing, Craddock rightly insists that preaching implies orality and not textuality. Craddock's emphasis on meaningful communication with one's hearers deserves high appreciation. Too often a viewpoint is held by some preachers that a written copy on the desk guarantees a well-communicated sermon from the pulpit. In fact, the final test for a communicative sermon is 
the "landing" of the sermon in the midst of the congregation, not (only) on the preacher's desk. The way from expectation to fulfilment should be embedded in the sermon at the desk of the preacher and utilised from the pulpit.

A third strength of Craddock's strategy for effective communication in preaching is the central place it gives to the congregation. Craddock's homiletic strategy has been influenced by his ecclesiology. For example, he claims that a preacher does not study the text alone, or without the people, but rather, studies the biblical text from the perspective of the congregation's respective situations (Craddock, 1981:123-125). Not only studying the Bible while keeping the congregation in mind, but also his point of departure in the sermon itself - experiences known to the congregation, guiding the congregation through the "journey" of the sermon to a personal conclusion - confirms his concern for the congregation. Not only the congregation must experience the Word, but also the preacher's "... effective delivery is by re-experiencing the message as it is being spoken" (Craddock, 1985:218). This experiencing the message implies in-depth communication (Mitchell, 1993:227).

A fourth issue to discuss in this regard is Craddock's view on the function of imagination and imagery in inductive preaching. The use of imagination and imagery in communicating the Word of God to a congregation (cf. subdivision 4) should be evaluated positively. The primary function of imagery in a sermon is to elucidate and to concretise the text for the congregation. It would have added value to the work of Craddock if he had elaborated in more detail on the power of metaphors in a sermon, especially because of his emphasis on the experiences of the hearer. Recent research has for example highlighted the power of metaphors to create emotional experiences in the hearer on account of new perspectives visualised (Brits, 2001:145; cf. Feltman, 1996:33).

A last point of comment relates to the insistence that there can be no movement without singleness of theme. Craddock emphasises the importance of reducing the message of the text to a single affirmative idea that contributes, he argues, to the preparation, delivery and reception of a sermon. Eslinger (1987:125), however, states "the weak link in his approach is the assumption that the interpretive payoff of every text is a proposition which then becomes the homiletic payoff of every sermonic form". What happens, asks Eslinger, when the preacher is working with one of Jesus' parables or one of the Johannine signs whose messages simply refuse to be reduced to a single simple affirmative sentence? In such circum- 
stances a preacher's options are limited: either impose a theme upon the text from the outside or sacrifice sermonic unity. For hermeneutical and homiletical reasons, neither option is attractive.

\section{Conclusion}

This exploration and evaluation of the homiletical views of F.B. Craddock have brought to the fore the following elements:

- The inductive form of preaching has advantages for preaching, in contrast to deductive preaching as a one-sided form of preaching. The strong views of Craddock on inductive preaching may, however, also lead to a one-sided form of preaching, the inductive form.

- The authors of this article would like to stress the function and homiletical validity of both forms of preaching - inductive and deductive - and would even recommend a combination of an inductive-deductive approach in the same sermon whenever it would be applicable, for example, in the light of the genre of a preaching text.

- The structure of a sermon should be a prolonging of the structure of the preaching text, fully taking into consideration and actualising the movements in the preaching text itself.

- The Word of God should be proclaimed fearlessly, but in an empathetic way, accommodating also the questions in the hearts of the hearers. In this regard the utilisation of imagery, especially suitable metaphors and an applicable way of preaching narrative material, can be profitable for our time.

Having explored and evaluated the inductive form of preaching and having highlighted some positive aspects, a preacher preparing a sermon should always keep the following in mind: To master the "technique" to make a sermon is a process in itself. It is, however, quite a different process to deliver a message in such a way that it serves to remove the veils hiding the face of God.

\section{List of references}

ADAMS, J.E. 1982. Preaching with purpose. Grand Rapids: Zondervan.

BANG, S.J. 2004. The form of the sermon and effective communication. A homiletical study. Potchefstroom: North-West University. (Ph.D. thesis.)

BRITS, H.J. 2001. Die transformasiekrag van die metafoor in die geloofspraksis met spesiale verwysing na prediking. Pretoria: Universiteit van Suid-Afrika.

(D.Th.-proefskrif.) 
BUTTRICK, D. 1994. A captive voice. The liberation of preaching. Westminster: John Knox.

CALLAHAN, K.L. 1999. Preaching grace. Possibilities for growing your preaching and touching peoples' lives. San Francisco: Jossey-Bass.

CHAPELL, B. 1995. Components of expository preaching. Preaching, 101(6):414.

COX, J.W. 1990. How useful is inductive preaching? Pulpit Digest, 82(1):62-70, May/Jun.

CRADDOCK, F.B. 1978. Overhearing the Gospel. Nashville: Abingdon.

CRADDOCK, F.B. 1981. As one without authority. 3rd ed. Nashville: Abingdon.

CRADDOCK, F.B. 1985. Preaching. Nashville : Abingdon.

DAVIS, H.G. 1958. Design for preaching. Philadelphia: Fortress.

DE WET, F.W. 1995. Die kritiese element in die luisterproses - 'n homiletiese studie. Potchefstroom: PU vir CHO. (Th.M.-verhandeling.)

DINGEMANS, G.D.J. 1991. Als hoorder onder de hoorders. Een hermeneuties homiletiek. Kampen: Kok.

ESLINGER, R.L. 1987. A new hearing: living opinions in homiletic method. Nashville: Abingdon.

FELTMAN, R.W. 1996 Preaching for transformation. Columbia: Theological Seminary. (D.Min. thesis.)

GOLDSWORTHY, G. 2000. Preaching the whole Bible as Christian Scripture. Grand Rapids: Eerdmans.

HAMILTON, D.L. 1992. Homiletical handbook. Nashville: Broadman.

JANSE VAN RENSBURG, J. 2000. The paradigm shift. An introduction to postmodern thought and its implications for theology. Pretoria: Van Schaik.

JANSE VAN RENSBURG, J. 2003. Narrative preaching. Acta Theologica Supplementum 4.

JOHNSTON, G. 2001. Preaching to a postmodern world: a guide to reaching twenty first-century listeners. Grand Rapids: Baker.

LAWSON, S.J. 2001. The priority of Biblical preaching: An expository study of Acts 2:42-47. Bibliotheca Sacra, 158(630):198-217.

LONG, T.G. 1989. Preaching and the literary forms of the Bible. Philadelphia: Fortress.

LONG, T.G. 1993 And how shall they hear? The listener in contemporary preaching. (In O'Day, G.R. \& Long, T.G., eds. Listening to the Word. Nashville: Abingdon. p. 167-188.)

MAYHUE, R.L. 1990. Rediscovering expository preaching. The Master's Seminary Journal, 1(2):109-125.

MITCHELL, H. 1993. The hearer's experience of the Word. (In O'Day, G.R. \& Long, T.G., eds. Listening to the Word. Nashville: Abingdon. p. 223-242.)

PIETERSE, H.J.C. 1979 Skrifverstaan en prediking. Pretoria: NG Kerkboekhandel.

PIETERSE, H.J.C. 1985. Verwoording en prediking. Pretoria: NG: Kerkboekhandel.

PIETERSE, H.J.C. 1991. Gemeente en prediking. Halfway House: NG Kerkboekhandel.

PIETERSE, H.J.C. 2001. Prediking in 'n konteks van armoede. Pretoria: Unisa.

ROBINSON, H.W. 2001. Biblical preaching. The development and delivery of expository messages. Grand Rapids: Baker. 
STRYDOM, M.C. 1989. Eksemplaries - heilshistories? Voortsetting van 'n onvoltooide gesprek. Bloemfontein: VCHO.

TAYLOR, B.B. 1993. Preaching the body. (In Long, T.G. \& O'Day, G.R., eds. Listening to the Word. Nashville: Abingdon. p. 207-221.)

VAN DER VYVER, L. DU P. 1990. Die rol van die hoorder in die prediking. Potchefstroom: PU vir CHO. (Th.M.-verhandeling.)

VAN HARN, R.E. 1992. Pew rights. Grand Rapids: Eerdmans.

VENTER, C.J.H. 2002. Expository preaching - a re-evaluation. Paper delivered at a conference of the Evangelical Homiletical Society. Chicago. Oct. 2002.

VENTER, C.J.H. 2004. Die Woord van God - toepaslik maak of toepaslik preek? In die Skriflig, 38(4):473-493.

VOS, C.J.A. 1995. Die blye tyding. Pretoria: RGN.

WILLHITE, K. 1992 Audience relevance in expository preaching. Bibliotheca Sacra, 149(594):355-369.

WILSON, P.S. 1993. Beyond narrative: imagination in the sermon. (In Long, T.G. \& O'Day, G.R., eds. Listening to the Word. Nashville: Abingdon. p. 131-146.)

\section{Key concepts:}

imagination and imagery

inductive preaching

movements in the sermon

sermon structure

\section{Kernbegrippe:}

bewegings in die preek

induktiewe prediking

preekstruktuur

verbeeld-ing, beeldspraak 
